\section{Ulster's New Universily}

THE official opening last week of the latest university in the United Kingdom, the New University of Ulster, at Coleraine, County Londonderry, went by virtually unnoticed. The press and the British people outside Northern Ireland were no doubt more concerned with the student occupation of the London School of Economies and the weekend demonstration against the war in Vietnam. But the establishment of a second university in that forgotten corner, Ulster, could well turn out in the long run to be a much more significant development than the addition of a new university anywhere olse in Britain or, for that matter, the recent rioting in Londonderry.

For one thing, there are fewer opportunities for higher education in Ulster then in the rest of Britain; there are, for example, no colleges of advanced technology and only one university-Queen's University, Belfastfor a population of 1.5 million. If everything goes according to plan, Queen's University and the New University should provide between 8,000 and 9,000 places by the mid-seventies for an expected population of about 12-13,000 applicants with the required qualifications. The New University, providing locally trained manpower, should also act as a focus for attracting new industries to Northern Ireland, which always suffers from levels of unemployment four or five times higher than those in the rest of Britain. But it shculd do more than provide education and jobs. If the recent behaviour of the students at Queen's University is anything to go by, the New University should have a considerable liberalizing influence, increasing mutual religious tolerance and civil rights for Ulstermen, and counteracting the militant Protestantism which is never far from the surface in Ulster.

By all accounts, the very fact that the university is in Coleraine rather than the county town Londonderry is to some people symptomatic of the religious hatreds which still prevail in Northern Ireland. Londonderry, the scene of recent civil rights rioting, is a predominantly Catholic town in a Protestant area, and cynics say that no government of Northern Ireland would build a university there for that reason alone. But it is impertinent to suggest that the Lockwood Committee on Higher Education in Northern Ireland, which recommended the Coleraine area in its report in 1965, was in any way influenced by such prejudices. The committee had its own good reasons for its choice. The university had to be built away from Belfast so as not to increase further Belfast's dominant position in the economic and cultural life of Ulster. At the same time the university had to be accessible, and in terms of travelling time Coleraine is convenient both to Northern Ireland's largest civil airport and to Belfast. Furthermore, Coleraine is close to holiday resorts which have plenty of accommodation outside the holiday season suitable for students.

The university does have, however, an outpost in Londonderry, McGee University College. McGee, a sort of liberal arts college, has always been a problem because it has no power to award its own degrees. Previously, it has provided its students with the first two years of their degree courses before sending them to Trinity College, Dublin, to complete the last two years and get a degree. The intention now is to incorporate McGee into the New University, and a Bill to this effect is now before the Northern Ireland Parliament (where it has met with opposition). In the meantime the New University and MeGee College have made their own arrangements and several of the humanities faculties of the New University are housed at McGee. This, of course, can only be a temporary arrangement, but the Northern Ireland Government has made it clear that McGee cannot be closed down, which would be the sensible thing to do as far as the university is concerned. If that were to happen, the Government would be accused of anti-Catholic feeling and of removing the only place of higher education in the town of Londonderry, one of the places hardest hit by unemployment. Although the Ulster Government has been fairly successful in attracting industry to most of the province, it has conspicuously failed to persuade companies to open factories in the town of Londonderry. The most likely solution seems to be that McGee will eventually become a postgraduate centre of the university, but everybody will have to tread very carefully, and the university will have to carry with it the support of the people of Londonderry when the decision is made.

Despite its unique problems the New University has by any standards been quickly built. Immediately after the Lockwood Committee reported in 1965, the Northern Ireland Government announced its intention of building a university in Coleraine. The site was selected in 1965, the Vice-Chancellor, Professor N. A. Burges of Liverpool University, appointed at the beginning of 1966, and the building begun in the summer of 1967. This is the first term for undergrad. uates and about 300 are housed at Coleraine and about another 50 at McGee in Londonderry. Sixty-five staff members have been appointed. Because of Northern Ireland's curious semi-autonomous status, the New University, like Queen's University, receives its funds from the Northern Ireland Ministry of Education, not from the University Grants Committee. This means of course that the UGC's letter of August 1, putting a stop to new contracts for building, does not apply. On the other hand, the Northern Ireland Government takes advice from the UGC, and the Ulster universities receive roughly the same treatment as the rest of Britain's universities. As a result the development of the New University is likely to be delayed by about a year over the next five years, but the university has been given the go-ahead for work costing $£ 1.9$ million between now and 1970-71. The economic situation should not be allowed to delay more than that the development of a university which could help to alleviate so many of Ulster's problems. 